\title{
EUPHORBIA NOCENS, FORMERLY A VARIETY OF EUPHORBIA HIRTA (EUPHORBIACEAE)
}

\author{
Victor W. SteinmanN \\ Instituto de Ecología, A.C., Centro Regional del Bajío \\ Apartado postal 386, 61600 Pátzcuaro, Michoacán
}

\begin{abstract}
Euphorbia hirta is a widespread species distributed throughout tropical and subtropical regions of the world. Four varieties of this taxon have been recognized, although many authors have chosen to treat one of these, Euphorbia hirta var. procumbens, at the rank of species as E. ophthalmica. In this article it is argued that the varieties of Euphorbia hirta should indeed be treated as species. For this reason, Euphorbia hirta var. nocens is elevated to Euphorbia nocens. This species differs from E. hirta in possessing larger, darkercolored seeds and glomerules of cyathia that are restricted to the ends of the primary branches. It is endemic to Mexico and occurs at elevations of 1500 to $2400 \mathrm{~m}$, primarily in pine-oak forest and resulting secondary vegetation. A morphological description of Euphorbia nocens is given, as well as a list of specimens examined. A key to separate this species from E. hirta, E. lineata, and E. ophthalmica is also provided.
\end{abstract}

Key words: Euphorbia, Euphorbia hirta, Euphorbia nocens, Euphorbiaceae, Mexico, subgenus Chamaesyce.

\section{RESUMEN}

Euphorbia hirta es una especie ampliamente distribuida a través de las regiones tropicales y subtropicales del mundo. Anteriormente fueron reconocidas cuatro variedades de este taxon, aunque muchos autores prefieren tratar una de ellas, Euphorbia hirta var. procumbens, a nivel de especie como E. ophthalmica. En este artículo se presentan evidencias que apoyan la decisión de que las variedades de $E$. hirta deberían de ser tratadas como especies. Por consiguiente, se eleva E. hirta var. nocens a E. nocens, que difiere de E. hirta por tener semillas más grandes y más obscuras y por formar glomérulos de ciatios solamente en posición terminal. Es endémica de México, prosperando principalmente en bosques de pino-encino y su vegetación secundaria en altidudes de 1500 a 2400 m. Se incluye una descripción morfológica y una lista de especímenes examinados. También se proporciona una clave para separar esta especie de E. hirta, E. lineata y E. ophthalmica.

Palabras clave: Euphorbia, Euphorbia hirta, Euphorbia nocens, Euphorbiaceae, México, subgénero Chamaesyce. 
Euphorbia hirta L. is one of the most successful and widespread members of the Euphorbiaceae, and this polymorphic, "weedy" species occurs in tropical and subtropical regions around the world. Like the majority of Euphorbia subg. Chamaesyce, it is native to the Americas. Its presence in the Old World is apparently the result of introduction, although it has occurred there for at least 250 years and the type was from India (Wheeler, 1939). Wheeler (1939) recognized four varieties of this species. In addition to var. hirta (referred to by him as var. typica), he accepted var. procumbens (Boiss.) N.E. Br. ${ }^{*}$ and proposed two additional taxa, var. destituta L.C. Wheeler (from Peru) and var. nocens L.C. Wheeler (from Mexico). The purpose of this paper is to discuss the status of these varieties and elevate one of them, Euphorbia hirta var. nocens, to the rank of species.

The distinctiveness and rank of Wheeler's varieties have by no means been universally accepted. Many subsequent authors (e.g., Burch, 1966; Webster and Huft, 1988) treat var. procumbens at the rank of species as Euphorbia ophthalmica Pers. (=Chamaesyce ophthalmica (Pers.) D.G. Burch), whereas others continue to treat it as a variety of E. hirta (e.g., Subils, 1977; Calderón de Rzedowski, 2001). Variety nocens has been recognized by some (Steinmann and Felger, 1997; Calderón de Rzedowski, 2001), but relegated to synonymy of typical Euphorbia hirta by others (Govaerts et al., 2000). Variety destituta has slipped into relative obscurity since it was first described, and no mention of it can be found in the recent checklist of Peruvian plants (Brako and Zarucchi, 1993). Like var. nocens, it was not recognized by Govaerts et al. (2000). From my field experience with three of these taxa in Central Mexico and from the examination of a large amount of herbarium material from throughout the world, I believe that the four varieties recognized by Wheeler are indeed distinct and that the best rank for them is that of species. This is in contrast to my previous opinion (Steinmann and Felger, 1997) that var. nocens belonged as a variety of Euphorbia hirta. I have seen only two collections that appear to represent Wheeler's var. destituta and have not reached a final conclusion on its status. Therefore, the remainder of this article will focus on the other taxa recognized by Wheeler, without further consideration of his var. destituta.

The reasons that I believe these taxa should be recognized as distinct species and not as infraspecific components of Euphorba hirta are various. Collectively they are separable by a number of features (see key and discussion below), and their differences are comparable to those possessed by many other closely related taxa of Euphorbia subg. Chamaesyce that traditionally have been treated as species. In

\footnotetext{
*It must be clarified that the name Euphorbia procumbens DC. (published in 1813) is an illegitimate homonym of $E$. procumbens Mill. (published in 1768). Boissier (1862) reduced it to a variety of Euphorbia pilulifera L. According to article 58 of The International Code of Botanical Nomenclature (St. Louis Code), this name has priority from 1862, not 1813, and its author is Boissier. Therefore, when treated as a variety of Euphorbia hirta, the correct author citation is Euphorbia hirta L. var. procumbens (Boiss.) N.E. Br. instead of E. hirta L. var. procumbens (DC.) N.E. Br.
} 
addition, there are differences in both range and habitat preference: E. hirta, as previously mentioned, is widespread in tropical and subtropical regions throughout the world; E. ophthalmica is amply distributed and only sporadically introduced in the Old World, occurring principally in tropical regions both in lowland and high montane habitats; and E. nocens is endemic to Mexico where it is found primarily in pine-oak forest and the secondary vegetation derived from it. Furthermore, these taxa present no signs of intermediacy and consistently differ even when occurring together; thus, they presumably possess well-defined barriers to gene flow. Finally, I am not convinced that Wheeler's varieties form a monophyletic assemblage, and E. nocens actually appears more similar to Euphorbia lineata S. Watson then it is to $E$. hirta. For these rationale, the following combination is made.

Euphorbia nocens (L.C. Wheeler) V.W. Steinm., comb. nov. Basionym: Euphorbia hirta L. var. nocens L.C. Wheeler, Contr. Gray Herb. 127: 70. 1939. Type: México, Michoacán, vicinity of Morelia, Loma del Zapote, 1850 m, 11 July 1909, Arsène 3038 (holotype US!).

Annual or short-lived perennial herb, prostrate to ascending, from a slender taproot bearing numerous, threadlike secondary roots; stems solitary or many arising from near the base, to ca. $30 \mathrm{~cm}$ long, mostly little-branched above the base, internodes $0.5-7(11) \mathrm{cm}$ long, terete to dorsiventrally flattened and winged (i.e., with a sharp, narrow margin), 0.7-1.0 $\mathrm{mm}$ wide near the tips, pubescence uniformly distributed around the circumference of the stem or more frequently considerably denser on the upper surface, indumentum often of two types, one strigulose with appressed to ascending, recurved to crisped hairs 0.1-0.6 mm long, the other hirsute with stiff, spreading, straight to slightly wavy hairs $0.5-1.5 \mathrm{~mm}$ long, these dark-yellow (rarely whitish), multicellular with conspicuous reddish cross-walls; leaves opposite, stipules interpetiolar, separate or rarely united, narrowly triangular to subulate, 1.5$2.5 \mathrm{~mm}$ long, sometimes with short secondary subulate divisions arising from near the base, pilose to villous, petioles 1-2(3) mm long, hirsute to strigose, laminas ovate, oblong, to elliptic, $0.8-3.8 \mathrm{~cm}$ long, $0.4-1.6 \mathrm{~cm}$ wide, asymmetrical, sometime slightly falcate, often with a conspicuous red spot in the center, the upper surface glabrate, the lower surface pilose to villous or strigose, obtuse or rarely acute at the apex, oblique at the base, margin serrulate; cyathia very numerous in dense, leafless, terminal glomerules, peduncles $0.4-1.3 \mathrm{~mm}$ long, glabrous to sparsely pubescent, involucre narrowly obconical, $0.5-0.8 \mathrm{~mm}$ long (excluding the lobes, glands, and appendages), 0.4-0.7 $\mathrm{mm}$ wide below the glands, strigose on the outside, glabrous to minutely strigose within, lobes narrowly triangular to subulate, 0.1-0.2 mm long, glands 4 per involucre, stipitate, circular, ca. $0.1 \mathrm{~mm}$ in diameter, slightly concave, appendages 0.1-0.2 mm long, ca. $0.2 \mathrm{~mm}$ wide or apparently absent, rotund, oblong to shortly flabellate, margin entire; staminate flowers 5-8 per involucre; gynophore pubescent, exserted $0.2-0.9 \mathrm{~mm}$, ovary globose, hoary, styles 3 , cylindrical to slightly clavate, $0.3-0.4 \mathrm{~mm}$ long, divided from ca. halfway to nearly the base, terete or slightly capitate at the apex; capsules broadly ovoid, $1.5-1.8 \mathrm{~mm}$ long, 1.6-1.8 mm 
wide, strongly 3-lobed, widest below the middle, slightly sulcate between the cocci, strigose-puberulent with vermiform hairs $0.1-0.2 \mathrm{~mm}$ long, often glabrate in spots, columella 1.2-1.4 mm long; seeds narrowly ovoid-quadrangular, 1.1-1.3 mm long, 0.6-0.7 $\mathrm{mm}$ wide, dorsal facets $0.5-0.6 \mathrm{~mm}$ tall, concave, rugulose or with low, rounded transverse ridges that do not pass through the dorsal keel, truncate at the base, pointed at the apex with a rounded tip, dorsal keel prominent, dark red-brown to almost black.

Euphorbia nocens is endemic to Mexico and ranges from Sonora and Chihuahua to the State of México and the Distrito Federal. In addition, I have seen one collection from San Luis Potosí. Within its range, it is sporadic but often locally common. It occurs at elevations from (1300)1500 to $2400 \mathrm{~m}$, primarily in pine-oak forest and the secondary scrubs, grasslands and roadside marshes derived from this vegetation. Like Euphorbia hirta, E. nocens has a tendency to occur in disturbed sites, but in contrast to E. hirta, it apparently has not extended greatly outside of its original geographic range. In both Pátzcuaro and Morelia, Michoacán, I have observed Euphorbia nocens growing side-by-side with E. ophthalmica. In such cases, the two species are distinct and possess no signs of intermediate morphology. I have also seen a mixed collection of Euphorbia nocens and E. hirta (Rzedowski 52686), and again the two appear completely distinct.

Euphorbia nocens was separated from the other varieties of $E$. hirta by the possession of larger capsules and seeds, 1.6-1.7 mm (vs. 1-1.5 mm) long and 1.15$1.2 \mathrm{~mm}$ (vs. 0.7-0.9 mm) long, respectively (Wheeler, 1939). No additional features were mentioned by Wheeler, but Steinmann and Felger (1997) noted that this taxon is also distinguished by the color of the seeds, which is mostly dark red-brown to nearly black. In the remainder of Wheeler's varieties the seeds are pale grayish brown, orange-brown or pinkish. Euphorbia nocens shares with E. ophthalmica, and the apparently closely related $E$. lineata, the possession of glomerules of cyathia that are terminal and restricted to ends of leafy branches. In Euphorbia hirta the glomerules of cyathia are both terminal as well as axillary. The following key will distinguish these taxa.

1. Seeds (1)1.1-1.3 mm long, dark brown to almost black.

2. Stems with adpressed or weakly ascending hairs only; involucral appendages 0.4-0.7(1.2) $\mathrm{mm}$ long; seeds plumply ovoid in distal view, with dull angles, 0.7-0.9 $\mathrm{mm}$ wide, the dorsal facets flat or convex and 0.7-0.8 tall E. lineata

2. Stems, especially towards the tip, with numerous hairs spreading at right angles, although these interspersed with adpressed or ascending hairs; involucral appendages 0.1-0.2 mm long or apparently absent; seeds narrowly ovoid-pyramidal in distal view, with sharp angles, 0.6-0.7 $\mathrm{mm}$ wide, the dorsal facets concave and $0.5-0.6 \mathrm{~mm}$ tall ................................. E. nocens 1. Seeds $0.7-0.9(1.1) \mathrm{mm}$ long, pale grayish brown, orange-brown, or pinkish. 
3. Glomerules of cyathia terminal as well as axial, when axial sessile or on prominent leafless peduncles .......................................... E. hirta

3. Glomerules of cyathia terminal on the primary stems only or rarely axial and if so then terminal on short, leafy shoots E. ophthalmica

Additional specimens examined. MEXICO. Chihuahua: Bermúdez, $28^{\circ} 15^{\prime} 44^{\prime \prime} \mathrm{N}$, 10902'50"W, Turner 85-94 (ARIZ); mpio. Temosachi, Nabogame, $28^{\circ} 30^{\prime} \mathrm{N}$, $108^{\circ} 30^{\prime} \mathrm{W}$, Laferrière 1563 (ARIZ). Distrito Federal: Ciudad de México, Colonia Campestre Churubusco, Quijano 99" $B$ " (ENCB). Durango: along rte. 40, ca. $10 \mathrm{mi}$ $\mathrm{E}$ of Los Mimbres and $2 \mathrm{mi}$ S of Río Chico, McGill et al. 9422 (ASU); $67 \mathrm{mi}$ from Villa Union, Oliver et al. 823 (MO). Guanajuato: mpio. Salvatierra, $3 \mathrm{~km}$ al N de Santiago Maravatío, Rzedowski 38810 (ENCB, IEB, MEXU); mpio. Salvatierra, 4 km al NE de Salvatierra, sobre la carretera a Celaya, Rzedowski 38991 (ENCB, IEB), 49120 (IEB); mpio. Acámbaro, cerca de Inchamácuaro, Rzedowski 39404 (IEB); mpio. Salvatierra, Salvatierra, Rzedowski 39859 (IEB); mpio. Cortazar, 2 km al NW de La Gavia, sobre el camino a Cortazar, Rzedowski 40921 (IEB); mpio. Salvatierra, Santiago Maravatío, cerca de Salvatierra, Rzedowski 49112 (IEB). Jalisco: about $12 \mathrm{mi}$ SE of Guadalajara, Barkley et al. 75 (MEXU); MEX 15, $52 \mathrm{~km}$ S of Guadalajara, west end of Lake Chapala, Burch 5180 (MO); 18 km 6 [sic] Tapalpa, Burch 5249 (MO); mpio. Cocula, Arroyo Colorado, sobre la carretera a Barra de Navidad, km 0.2 del camino a la Torre R.M.O. Quililla, $20^{\circ} 18^{\prime} \mathrm{N}, 103^{\circ} 54^{\prime} \mathrm{W}$, Carrillo-Reyes et al. 3602 (IEB); mpio. Zapotlanejo, La Mezquitera, Puente Grande, Díaz Luna 433 (MICH); mpio. Jocotepec, Potrero El Jaral, Machuca 3395 (F); ca. 5 road-miles SW of Santa Cruz de las Flores, McVaugh 16311 (MICH); ca. $10 \mathrm{~km}$ ESE of Guadalajara, $8 \mathrm{~km}$ (by road) W of Puente Grande, on MEX 80, 20³4'56"N, 103 $13^{\circ} 28^{\prime \prime}$ W, Steinmann 756 (ARIZ, MICH, RSA); MEX 15, 9 mi beyond turnoff to Autlan, near km 630, Weintraub \& Roller 196 (MICH); mpio. Zacoalco de Torres, La Playita, en la orilla de la laguna de San Marcos, S. Zamudio y F. Guevara 4222 (IEB). Edo. de México: mpio. Tepotzotlán, alrededores de la Presa de la Concepción, Rzedowski 26434 (ENCB). Michoacán: vicinity of Morelia, north of Loma del Zapote, Arsène 5372 (US); $8 \mathrm{~km}$ E of Morelia, MEX 15, Burch 2655 (DAV, MO); MEX 110, $23 \mathrm{~km} \mathrm{~W}$ of Zamora, Burch 2760 (DAV, MO); MEX 15, $12 \mathrm{~km} \mathrm{E} \mathrm{of} \mathrm{Quiroga,} \mathrm{Burch} 5115$ (MEXU, MO); mpio. Erongarícuaro, al NE de Puácuaro, Díaz B. 6334 (IEB); west of Tuxpan, intersection of MEX 15 and MICH 122, Kral 25525 (IEB); mpio. Churintzio, Ojo de Agüita-Sanguijuelas, Labat 1672 (ENCB, IEB, MEXU); E de Jesús del Monte, municipio de Morelia, 2100 m, C. Medina G. 1960. (EBUM); mpio. Tlazazalca, bordo en la desviación a La Yerbabuena, sobre la carretera a Churintzio, Ocampo \& Medellín 1050 (IEB); mpio. Sixto Verduzco, Cerro Tres Mezquites, Pérez \& García 1262 (EBUM, IEB); mpio. Tlazazalca, 2 km al O de La Yerbabuena, Pérez \& García 1386 (EBUM, IEB); mpio. Morelia, cerca del Puerto de los Copales, $8 \mathrm{~km}$ al E de Morelia, sobre el camino a Mil Cumbres, Rzedowski 40883 (IEB, MEXU); mpio. Indaparapeo, $4 \mathrm{~km}$ al S de Indaparapeo, sobre el camino a Las Peras, Rzedowski 51591 (IEB); mpio. Angamacutiro, vertiente S del Cerro de Tres Reyes, cerca de 
Angamacutiro, Rzedowski 52686c (IEB); mpio. Indaparapeo, $6 \mathrm{~km}$ al NE de Indaparapeo, Colonia Guadalupe, Soto 6436 (MEXU); mpio. Pátzcuaro, Pátzcuaro, Colonia Los Nogales, 19³2'13"N, 101³6'29" W, Steinmann 1689 (ARIZ, IEB, $\mathrm{MICH}$ ); en las afueras de Tuxpan hacia el este, $19^{\circ} 33^{\prime} \mathrm{N}, 100^{\circ} 27^{\prime} \mathrm{W}$, Vibrans 3099 (ENCB, MEXU). Nayarit: MEX 15, La Labor, Burch 5358 (MO); mpio. Nayar, Mesa

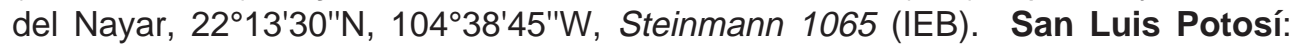
"chiefly in the region of San Luis Potosí, 22N," Parry \& Palmer 809 (MO, US). Sonora: $6.6 \mathrm{~km}$ al O de Yécora, 28²1'42"N, 10959'06"W, Búrquez et al. 96-817 (MEXU), Búrquez et al. 96-910 (MEXU), Reina 96-443 (MEXU), Reina 96-457 (MEXU); $4.1 \mathrm{mi} \mathrm{W}$ of the Chihuahua border, $9.4 \mathrm{mi} \mathrm{E}$ of Maycoba on MEX 16, in Arroyo La Ciénaga de Camilo, 28²6'06.3"N, 108³3'36.8"W, Felger 94-326 (ARIZ); below Mesa Grande, closer to Yécora, 12 Aug 1987, Martin s. n. (ARIZ); ca. 1 km (by air) $S$ of Restaurant La Palmita, north slopes of Mesa del Campanero, $28^{\circ} 21^{\prime 30}$ "N, 10904'05"W, Reina 2000-500 (ARIZ, IEB); Yécora, 3 Sep 1991, Reina s. n. (ARIZ); Yécora, 28²2'20"N, 10855'30"W, Steinmann 1005 (ARIZ, DAV, IEB, $\mathrm{MICH})$.

\section{ACKNOWLEDGMENTS}

I thank Richard S. Felger and Graciela Calderón de Rzedowski for reviewing the manuscript and the following institutions for access to their collections: ARIZ, DAV, ENCB, F, IEB, MEXU, MICH, MO, RSA, and US.

\section{LITERATURE CITED}

Boissier, E. 1862. Euphorbieae. In: de Candolle, A. Prodromus Systematis Naturalis Regni Vegetabilis 15(2). Victor Masson \& Fils. Paris. pp. 3-188.

Brako, L., and J. L. Zarucchi. 1993. Catalogue of the flowering plants and gymnosperms of Peru. Missouri Botanical Garden, St. Louis. 1286 pp.

Burch, D. 1966. Two new species of Chamaesyce (Euphorbiaceae), new combinations, and a key to the Caribbean members of the genus. Ann. Missouri Bot. Gard. 53: 90-99.

Calderón de Rzedowski, G. 2001. Euphorbia. In: Rzedowski, G. Calderón de, J. Rzedowski, and collaborators. Flora fanerogámica del Valle de Mexico. 2nd. ed. Instituto de Ecología, A.C. and Comisión Nacional para el Conocimiento y Uso de la Bioversidad. Pátzcuaro. pp. 354-367.

Govaerts, R., D. G. Frodin, and A. Radcliffe-Smith. 2000. World checklist and bibliography of the Euphorbiaceae (with Pandaceae). World Checklists and Bibliographies 4. Royal Botanic Gardens. Kew. 1621 pp.

Steinmann, V. W. and R. S. Felger. 1997. The Euphorbiaceae of Sonora, Mexico. Aliso 16: $1-71$.

Subils, R. 1977. Las especies de Euphorbia en la República Argentina. Kurtziana 10: 83248. 
Webster, G. L. and M. J. Huft. 1988. Revised synopsis of Panamanian Euphorbiaceae. Ann. Missouri Botanical Garden 75: 1087-1144.

Wheeler, L. C. 1939. A miscellany of New World Euphorbiaceae, - II. Contr. Gray Herb. 127: $48-78$.

Recibido en enero de 2003.

Aceptado en julio de 2003. 